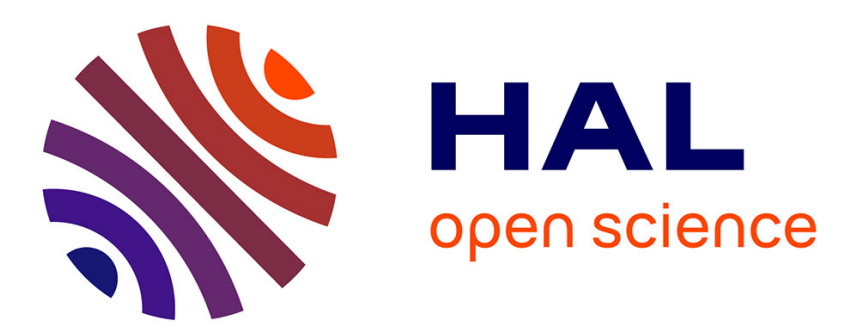

\title{
Relationship between physicochemical evolution and the failure process of flax fibers aged in water
}

Laetitia van Schoors, Nicolas Beauzieres, Thomas Cadu, Olivier Sicot, Emmanuel Keita

\section{- To cite this version:}

Laetitia van Schoors, Nicolas Beauzieres, Thomas Cadu, Olivier Sicot, Emmanuel Keita. Relationship between physicochemical evolution and the failure process of flax fibers aged in water. Journal of Materials Science, 2021, 18 p., graph., bibliogr. 10.1007/s10853-021-05908-z . hal-03161186

\author{
HAL Id: hal-03161186 \\ https://hal.science/hal-03161186
}

Submitted on 5 Mar 2021

HAL is a multi-disciplinary open access archive for the deposit and dissemination of scientific research documents, whether they are published or not. The documents may come from teaching and research institutions in France or abroad, or from public or private research centers.
L'archive ouverte pluridisciplinaire HAL, est destinée au dépôt et à la diffusion de documents scientifiques de niveau recherche, publiés ou non, émanant des établissements d'enseignement et de recherche français ou étrangers, des laboratoires publics ou privés. 


\title{
Relationship between physicochemical evolution and the failure process of flax fibers aged in water
}

\author{
Laetitia Van Schoors $^{1 *}$, Nicolas Beauzieres ${ }^{1}$, Thomas Cadu ${ }^{1,2}$, Olivier Sicot ${ }^{2}$, Emmanuel Keita ${ }^{3}$ \\ 1. MAST-CPDM, Univ. Gustave Eiffel, IFSTTAR, F-77454 Marne-la-Vallée, France \\ 2. DRIVE EA1859, Univ. Bourgogne Franche-Comté,F-58000 Nevers,France \\ 3. Laboratoire Navier, Univ. Gustave Eiffel, ENPC, CNRS, Marne la Vallée, France \\ Corresponding author: laetitia.van-schoors@univ-eiffel.fr
}

\begin{abstract}
Increasing environmental concern has put forward the use of flax fibers instead of glass fibers in composite materials. However, durability performances of these bio-fibers remain one of their main issues. This study focuses on the hydrothermal ageing of flax fibers. Flax tows were immersed in distilled water at a temperature of $80^{\circ} \mathrm{C}$ for different durations. The effect of the hydrothermal ageing on mechanical properties of flax tows was evaluated. Results showed a strong decrease in the maximal strength and the stiffness by $31 \%$ and $49 \%$ respectively until one week of ageing. Multi-scale analyses were realized to explain these evolutions. Morphological characterization highlighted a washing of fiber surfaces during the hydrothermal ageing, extracting amorphous components as pectins, lignins and amorphous hemicelluloses from cortical tissues. We showed that this morphological evolution impacted the fiber crystallinity. Based on a mechanical analysis, we showed that amorphous components extraction may be at the origin of the material softening. Moreover, the amorphous phase in particular the natural binder pectin would play a major role in the fiber stiffness but does not modify the flaws at the origin of failure.
\end{abstract}

Keywords: Flax fiber, Ageing, Failure, Griffith, microstructure

\section{Introduction}

Renewable resources like flax fibers have regained interest due to an increasing need for environmentalfriendly materials. Flax fibers offer many advantages. They are $\mathrm{CO}_{2}$ neutral, thermal and acoustic insulators and most importantly, they have high specific mechanical properties.

Flax fibers consist of cellulose, hemicellulose, lignin, pectin, waxes and water (cf. Table 1). They are at microscopic scale a complex multi-layer arrangement with a polygonal shape (5 to 7 sides), which is characteristic of bio-fibers. They have a diameter between 10 and $25 \mu \mathrm{m}$ and length between 15 and 36 $\mathrm{mm}[1-4]$ 


\begin{tabular}{ccccccc}
\hline $\begin{array}{c}\text { Cellulose } \\
\text { wt\% }\end{array}$ & $\begin{array}{c}\text { Hemicellulose } \\
\text { wt\% }\end{array}$ & $\begin{array}{c}\text { Pectin } \\
\text { wt\% }\end{array}$ & $\begin{array}{c}\text { Lignin } \\
\text { wt\% }\end{array}$ & $\begin{array}{c}\text { Waxes } \\
\text { wt\% }\end{array}$ & $\begin{array}{c}\text { Water } \\
\text { wt\% }\end{array}$ & References \\
\hline $62-72$ & $18.6-20.6$ & 2.3 & $2-5$ & $1.5-1.7$ & $8-12$ & {$[5]$} \\
$71-75$ & $18.6-20.6$ & 2.2 & 2.2 & 1.7 & 10 & {$[6]$} \\
61.4 & 16.7 & 1.8 & 2 & 1.5 & 10 & {$[7]$} \\
\hline
\end{tabular}

Table 1: Compositions of flax fibers by different authors.

Their multi-layer arrangements could be separated into three schematized parts (cf. Fig. 1). The primary cell wall (CWI), $0.2 \mu \mathrm{m}$ thick, is mainly made up of a little amount of cellulose and hemicelluloses, and an important quantity of pectins $[8,9]$. The secondary cell wall (CWII) is the thickest $(10 \mu \mathrm{m})$. This wall is composed of three layers (S1, S2 and S3). The thickest layer of the CWII is S2 and consists of highly crystalline cellulose micro-fibrils embedded in a matrix of amorphous hemicellulose, pectin and lignin [8, $10,11]$. The third part of the elementary fiber is called lumen. It is a small cavity, generally contributing to the water uptake [7]. At the mesoscopic scale, elementary fibers are bound together through a pectinbased interface called the middle lamella $[8,12]$.

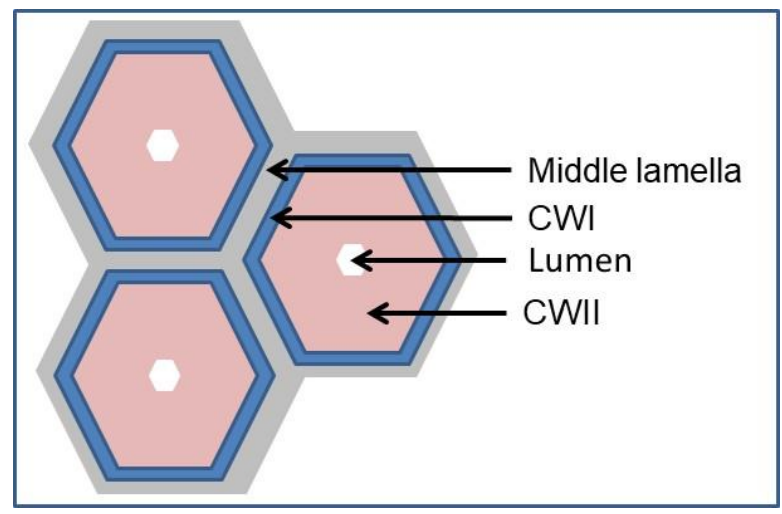

Fig. 1 Schematic representation of three sections of flax fiber

The chemical composition and the multi-layer arrangement confer to flax fibers very good tensile properties. Baley and Bourmaud [13] studied the mechanical properties of 12 varieties of flax fibers and found that their specific stiffness was higher than the one of glass fiber.

For flax tows (cf. Fig. 2), scale of fibers specimens widely used in multi-layer composites, the overall tensile properties could be slightly different. At the microscopic scale, the elementary flax fibers, which tensile properties have been discussed above, are widely studied. At the mesoscopic scale, the fiber bundle or the technical fiber (50 - $100 \mu \mathrm{m}$ diameter) consists of multiple elementary fibers $(10-40$ elementary fibers) tied together mainly by pectin through the middle lamella $[8,12]$. Finally, at the macroscopic scale, the flax tows are made up of an assembly of flax technical fibers aligned longitudinally so the overall cohesion is ensured by the pectin binders and some entanglement between fibers. This architecture gives strength to the tows as a whole [14]. 


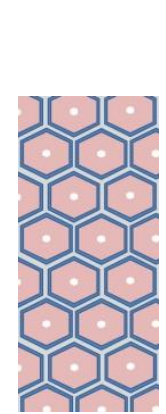

(a)

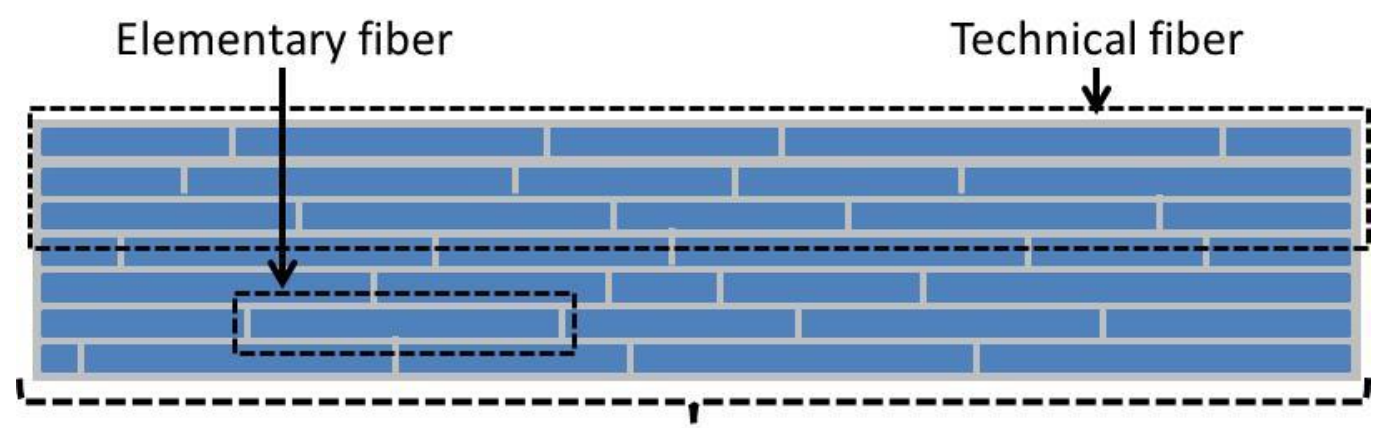

Flax tow

Fig. 2 Schematic representation of the flax tow adapted from Moothoo et al. [15] (a) cross-sectional view, (b) longitudinal view

Tensile properties of flax technical fibers and tows are significantly lower than tensile properties of elementary fibers. For identical lengths, the tensile strength of a technical fiber could be much lower than the one of an elementary fiber. Bos describes this phenomenon as bundle effects [16]. Beakou and Charlet. [17] suggest this lower strength results from the competition between the tensile breakage of elementary fibers and the shear fracture of the pectin, which bonds the fibers together. For Moothoo et al. [15], the mechanical properties of flax tows are essentially influenced by the fiber/fiber interface, i.e. the weak pectin interface between technical fibers. Charlet and beakou [18] have investigated the mechanical properties of the pectin interface within flax bundles. They found that mechanical properties of the interface were dramatically low. At least $90 \%$ of the tested samples had lower strength than the weakest fiber/matrix interface.

A summary of the average tensile properties of flax fibers at different scales is presented in Table 2 .

\begin{tabular}{lcccc}
\hline & $\begin{array}{c}\text { Strength } \\
(\mathrm{MPa})\end{array}$ & $\begin{array}{c}\text { Stiffness } \\
(\mathrm{GPa})\end{array}$ & Strain (\%) & Ref \\
\hline $\begin{array}{l}\text { Elementary fiber } \\
\begin{array}{l}\text { Single fiber } 33 \mathrm{~mm} \\
\text { length -19mm width) }\end{array}\end{array}$ & $945 \pm 200$ & $52.5 \pm 8.6$ & $2.07 \pm 0.45$ & {$[13]$} \\
$\begin{array}{l}\text { Technical fiber } \\
\begin{array}{l}(10-40 \text { elementary } \\
\text { fibers held together })\end{array}\end{array}$ & $264 \pm 127$ & - & - & {$[19]$} \\
$\begin{array}{l}\text { Flax bundle } \\
\text { (Bunch of technical } \\
\text { fiber held together) }\end{array}$ & $166 \pm 25$ & $22 \pm 2$ & $1.06 \pm 0.06$ & {$[15]$} \\
Fiber/Fiber interface & $2.9 \pm 2.4$ & $18.710^{-6} \pm$ & & {$[18]$} \\
\hline
\end{tabular}

Table 2: Average tensile properties of flax fibers at different scales. 
As stress is applied, the material stored the energy by elastic deformation. Above a critical strength, it is favorable to broaden preexisting flaws leading to failure [20]. This general energetic approach, develop by Griffith [20,21] has been applied to explain failure at the microscopic scale in various materials [22-27]. In this study, we refer to this theory to understand the relationship between macroscopic behavior and modification of the micro-structure.

The mechanical properties of the flax fibers could be influenced by other parameters and could be strongly dependent on the water content because of their hydrophilic nature. The main components involved in the water uptake of the fiber are cellulose, hemicellulose and pectin, due to their large number of hydroxyl groups [28-30]. Thuault et al. [31] have studied the influence of water ageing of flax fibers on the mechanical characteristics. Fibers were immersed up to two months at $20^{\circ} \mathrm{C}$ and $70^{\circ} \mathrm{C}$. Both temperatures seemed to have the same effect on mechanical properties. Thus, after two months of ageing, the failure strength decreased by more than $60 \%$, whereas the stiffness and the failure strain decreased by $55 \%$ and $26 \%$ respectively. Stamboulis et al. [14] have suggested that high-water content within the fiber might lead to the disorganization of the micro-fibrils network, resulting in lower mechanical properties without highlighting it.

Le Duigou et al. [32] have shown that the immersion (or washing) for $72 \mathrm{~h}$ at $23^{\circ} \mathrm{C}$ of flax fibers leads to a decrease of about $15 \%$ of failure strength and about $18 \%$ of the failure strain, but stiffness remained stable. According to these authors, in these conditions, those diminutions are non-relevant and they concluded that the washing at $23^{\circ} \mathrm{C}$ for $72 \mathrm{~h}$ did not significantly affect the mechanical properties of the fibers. Bourmaud et al. [33] analyzed the components extracted by immersion of flax fibers at $23^{\circ} \mathrm{C}$ for $72 \mathrm{~h}$, then $100^{\circ} \mathrm{C}$ for $1 \mathrm{~h}$. They found that immersion at room temperature extracted mainly oligomers from cortical tissues, while boiling water extracted polysaccharides from pectins. The same result was found by Alix et al. [11] using autoclave treatments of flax fibers. However, the influence of hydrothermal ageing was studied only at the elementary fiber scale.

The present paper aims at studying and understanding the effect of hydrothermal ageing on mechanical properties and embrittlement at the scale of the flax tows. We immersed flax tows for weeks in hot water at $80^{\circ} \mathrm{C}$ and measured mechanical and physicochemical properties. Comparing macroscopic behavior and molecular information, we show that extraction of amorphous phase plays a minor role on the macroscopic behavior but degradation of the amorphous compounds especially pectin is responsible for the softening of the material after ageing.

\section{Material and methods}

\subsection{Material and hydrothermal ageing}

The flax fibers used for this study were cultivated in Normandy and supplied by the company LINEO ( ). The manufacturing process begins with shelling and extracting the bundles from the flax stems. They are then scutched to clean them and to remove the shive residue. The fibers are aligned, stretched, then moistened with a water mist and continuously dried by passing through an infrared oven. The reinforcement is in the form of long fibers arranged unidirectionally without twisting. Then, the flax 
bundles are assembled in the form of a purely unidirectional reinforcing tape $40 \mathrm{~cm}$ wide, with a basis weight of $110 \mathrm{gr} / \mathrm{m}^{2}$ and branded under the name FlaxTape ${ }^{\mathrm{TM}} 110$. No weft thread is used to maintain the alignment of the fibers between them. Cohesion is guaranteed by the pectic binder on the surface of the fibers. Two layers (40 cm width and $35 \mathrm{~cm}$ length) were stored at $23^{\circ} \mathrm{C} / 50 \%$ relative humidity $\mathrm{RH})$ for one week without any drying or chemical pre-treatments, in order to keep the fibers in the same conditions before every test. Hydrothermal ageing was performed in an oven (MEMMERT) with a temperature set at $80^{\circ} \mathrm{C}$. Flax tow specimens were randomly cut from a layer, then immersed in distilled water at $80^{\circ} \mathrm{C}$. The ageing durations were 1 week and 3 weeks. After ageing, the tows were conditioned one week at $23^{\circ} \mathrm{C} / 50 \% \mathrm{RH}$ prior to tensile testing and microstructure analysis to limit the fluctuations in water content of the fiber, which are responsible for the variability in the mechanical properties of the flax fibers. So, the potential difference of water content will be in this case related to the fiber hydrophilic characteristic and not at the humidity rate in which the fibers are stored.

\subsection{Tow specimens}

A gauge length of $150 \mathrm{~mm}$ (5 mm width, $210 \pm 10 \mu \mathrm{m}$ thick) with a linear density de $0.55 \mathrm{~kg} / \mathrm{km}$ was used for tensile tests in this study, as recommended by Moothoo et al. [15] (Fig. 3). This gauge length was chosen because, according to Bos [16], for a gauge length shorter than $25 \mathrm{~mm}$, the behavior of the technical fiber was influenced by elementary fibers, resulting in high strengths. Besides, for gauge length longer than $100 \mathrm{~mm}$, the tensile properties are stable. So, for this author, when the gauge length is higher than the average elementary fiber length (15 to $36 \mathrm{~mm}$ ), the failure presumably occurs through the pectin interface of the fibers. Moothoo et al. [15] have observed the same behaviors and have pointed out a stabilization of the tensile properties as the gauge length increases.

After ageing, the specimens were dried at ambient air over one day, and then stuck on a thin aluminum sheet. Afterwards, as already mentioned, they were conditioned at $23^{\circ} \mathrm{C} / 50 \% \mathrm{RH}$ for 1 week before tensile tests.

Fig. 3 Flax tow specimen

\subsection{Tensile tests of tows}

Mechanical properties of the tows were determined using an INSTRON 5969 tensile machine equipped with a $2 \mathrm{kN}$ load cell at room temperature. Force-strain curves were then recorded at a constant crosshead displacement rate of $1 \mathrm{~mm} \cdot \mathrm{min}^{-1} .25$ specimens were tested for raw fibers, the same number of specimens were tested after 1 week and 3 weeks of immersion.

\subsection{Physicochemical analysis of the fiber}


A Scanning Electron Microscope (SEM FEI QUANTA 400) was used in the secondary electrons mode, at $7.5 \mathrm{kV}$ voltage and at a working distance of $7.5 \pm 0.1 \mathrm{~mm}$. The samples were bonded on adhesive carbon taps in order to inspect the surface of the fiber and the effect of water on these fibers. In order to avoid electronic charging, the specimens have been coated with a thin carbon layer.

The fiber crystalline microstructure was determined by X-ray diffraction (XRD) analysis in reflection mode. A PHILIPS PW 1830 diffractometer with CoKa1 $(\lambda=1,79 \AA)$ radiation set has been used. The $2 \theta$ angle range was $4-76^{\circ}$ and samples were laid on a silicon disc. One method was considered to assess the fiber crystallinity rate: to use a symmetrical Gaussian function and through Origin ${ }^{\mathrm{TM}}$ software, calculate the crystallinity rate by deconvolution. The apparent crystallinity is determined from the ratio of the area of the crystalline peaks to the total area including the amorphous halo with the following equation 1:

$$
C=100 . \frac{I_{\text {cr peak } 1}+I_{\text {cr peak } 2}+I_{\text {cr peak } 3}}{I_{\text {cr peak } 1+I_{\text {cr peak } 2}+I_{\text {non-cr }}+I_{\text {cr peak } 3}}}
$$

C: apparent crystallinity (\%),

$I_{\text {cr peakx }}$ is the area under the crystalline peaks at $16.8^{\circ}, 18.8^{\circ}$ and $25.9^{\circ}$ Inon-cr is the area of the amorphous halo.

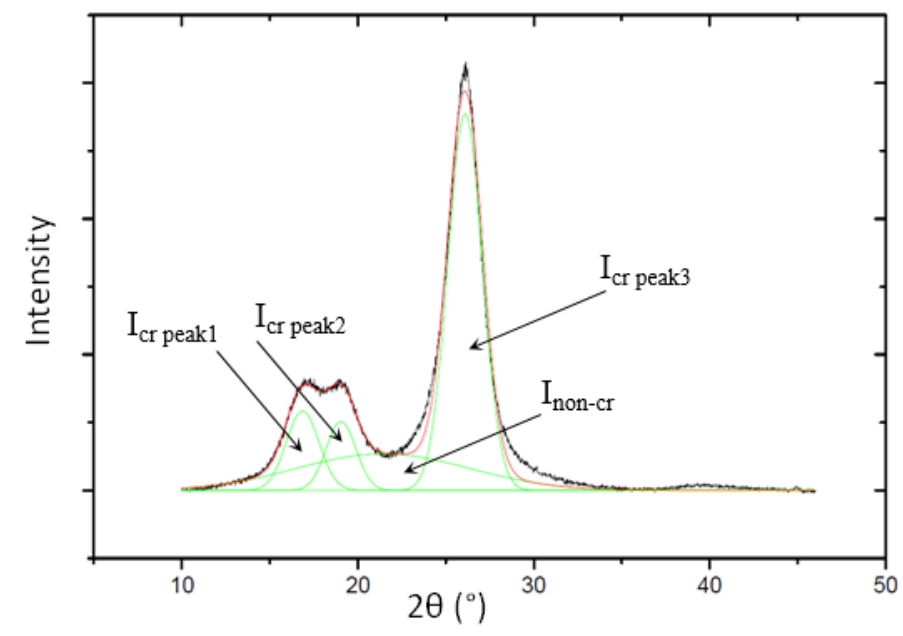

Fig. 4 X-Ray diffractogram of flax fibers (dark), the deconvolution's elementary peaks (green) and the sum of the peaks (red)

Fig. 4 shows the typical X-ray diffractometer of flax fibers. Four peaks can be noticed at $16.8^{\circ}, 18.8^{\circ}$, $25.9^{\circ}$ and $39^{\circ}$. Peaks at $16.8^{\circ}$ and $18.8^{\circ}$ may correspond to $(1 \overline{1} 0)$ and (110) planes respectively, whereas peaks at $25.9^{\circ}$ and $39^{\circ}$ are attributed to the (200), and (023) or (004) planes respectively [34]. The two well-defined peaks observed around $17^{\circ}$ are in accordance with Tserki et al. [34]. 
The chemical composition of the first few $\mu \mathrm{m}$ of the flax fibers surface was analyzed using Attenuated Total Reflectance Fourier Transform Infrared (ATR-FTIR) method. Spectra were recorded using a Nicolet impact 380 spectrometer and Durascope Diamond ATR equipment. 32 scans were collected on raw and aged fibers over the $4000-650 \mathrm{~cm}^{-1}$ spectral range, with a resolution of $4 \mathrm{~cm}^{-1}$.

Dynamic Vapor Sorption (SMS DVS-ADVANTAGE) was used to investigate the water uptake of flax fibers after hydrothermal ageing. The DVS is able to point out highly accurate mass changes in humid environments. Two ramps were recorded: 36 hours at $25^{\circ} \mathrm{C}$ and $90 \% \mathrm{RH}, 36$ hours at $25^{\circ} \mathrm{C}$ and $40 \%$ $\mathrm{RH}$.

\section{Results}

\subsection{Tensile behavior of flax tows}

The tensile behaviors of flax tows were characterized on one-week conditioned and aged specimens. Tensile tests were performed afterwards and their typical force-strain curve is provided Figure 5 . The tensile behavior of flax tows displays four periods. The first period $(0-0.05 \%$ strain) is non-linear whereas the second $(0.05-0.3 \%$ strain) is linear and was considered to calculate the stiffness of the tow. In the third period $(0.3-0.7 \%$ strain), the stress increase is no longer linear and reaches a maximum $\left(\sigma_{c}\right)$ for a critical strain of $\varepsilon_{c}$. Unlike elementary fibers, a second modulus E2 cannot be determined between 0.25 and $0.5 \%$ strain because the slope is not linear between 0.3 and $0.5 \%$ strain for flax tows. At higher strain, the force decreases until the complete failure of the tow. This general behavior is similar for aged samples with smaller stiffness, maximal strengths and higher critical strain. For our results to be statistically significant, each experiment was repeated on 25 samples.

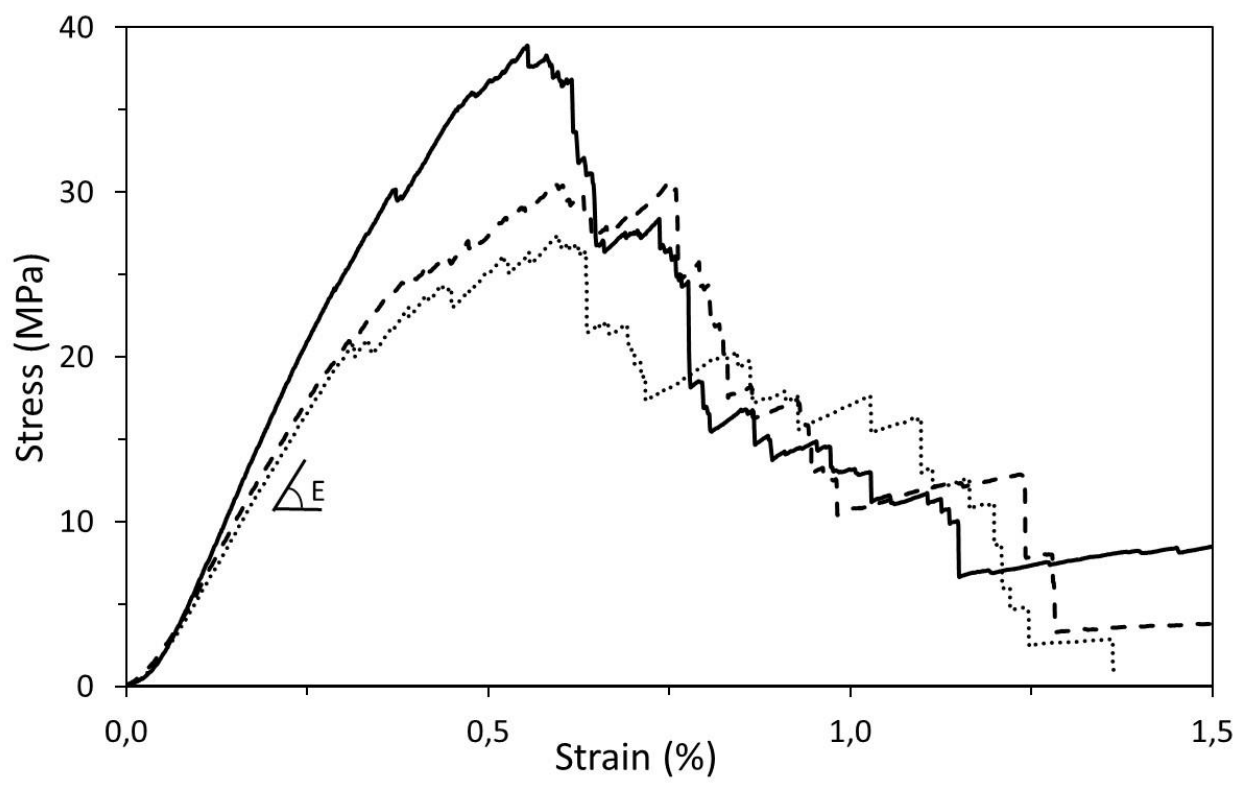


Fig. 5 Typical tensile behavior of flax tow unaged (-), aged 1 week (----) and aged 3 weeks (…)

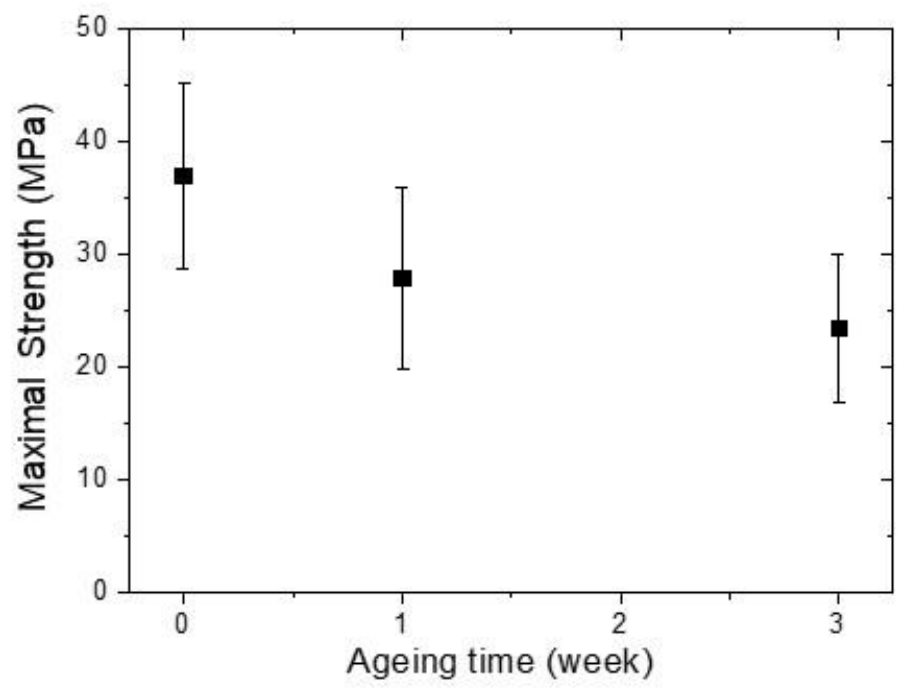

(a)

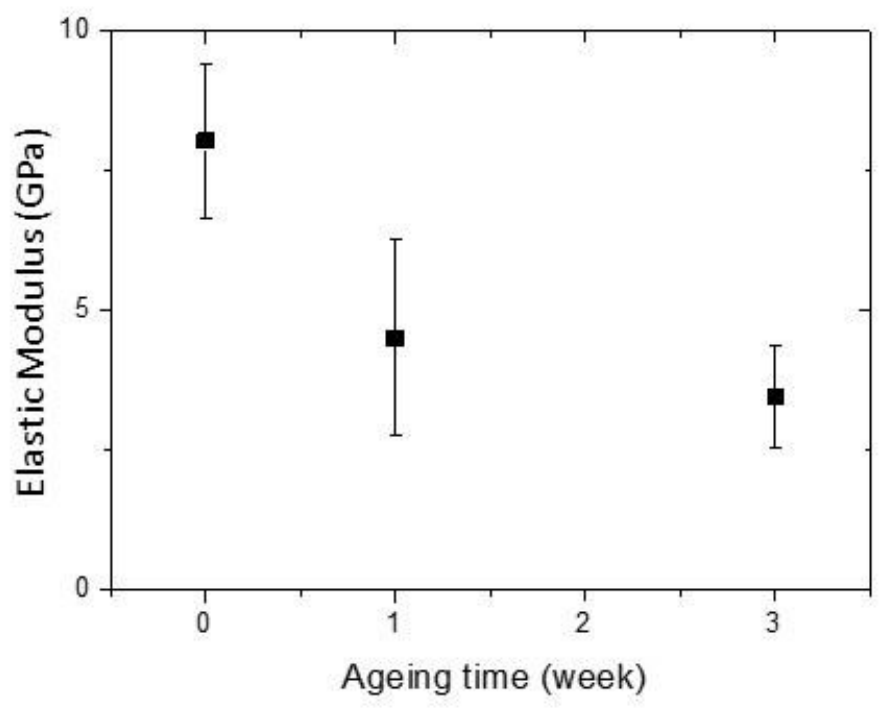

(b) 


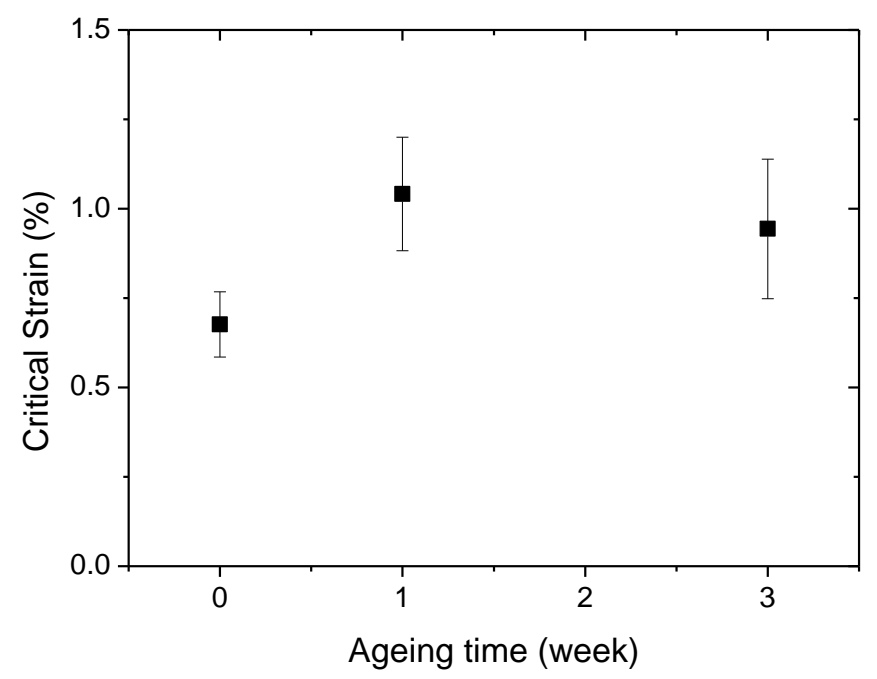

(c)

Fig. 6 Mechanical properties of flax tows as a function of ageing times (a) maximal strength (b) elastic modulus, (c) critical strain

The evolution of the mechanical properties of flax tows as a function of the ageing time is shown in Fig. 6. During the first week of ageing, water immersion affects the mechanical properties of the tows. Mechanical properties slightly evolve between one and three weeks. The average maximal strength and the average elastic modulus decreased by $25 \%$ and $44 \%$ respectively after one week of ageing; after three weeks these decreases reach $37 \%$ and $57 \%$. Besides, the failure strain increased by $40 \%$ in the same period. The standard deviation on tensile tests are high between 10 and $30 \%$ of the absolute values, nevertheless the evolution of elastic modulus and critical strain after one week is significant. However, the slight modification of the properties between one and three weeks is of the order of the uncertainty of the protocol.

To understand the mechanical evolutions, multi-scale analyses have been performed.

\subsection{Physicochemical analysis}

Firstly, the effect of one week of ageing on the hydrophilic behavior of the flax fiber has been evaluated by Dynamic Vapor Sorption (DVS). Fig. 7 presents the moisture adsorption behavior of raw fibers (black curve) and fibers after 1 week of hydrothermal ageing (red curve). A first isotherm was carried out at $25^{\circ} \mathrm{C}$ and $50 \% \mathrm{RH}$ for $60 \mathrm{~min}$. Two ramps were then processed: the first one at $25^{\circ} \mathrm{C} / 90 \% \mathrm{RH}$ during $36 \mathrm{~h}$ and the second one at $25^{\circ} \mathrm{C} / 40 \% \mathrm{RH}$ during $36 \mathrm{~h}$. 


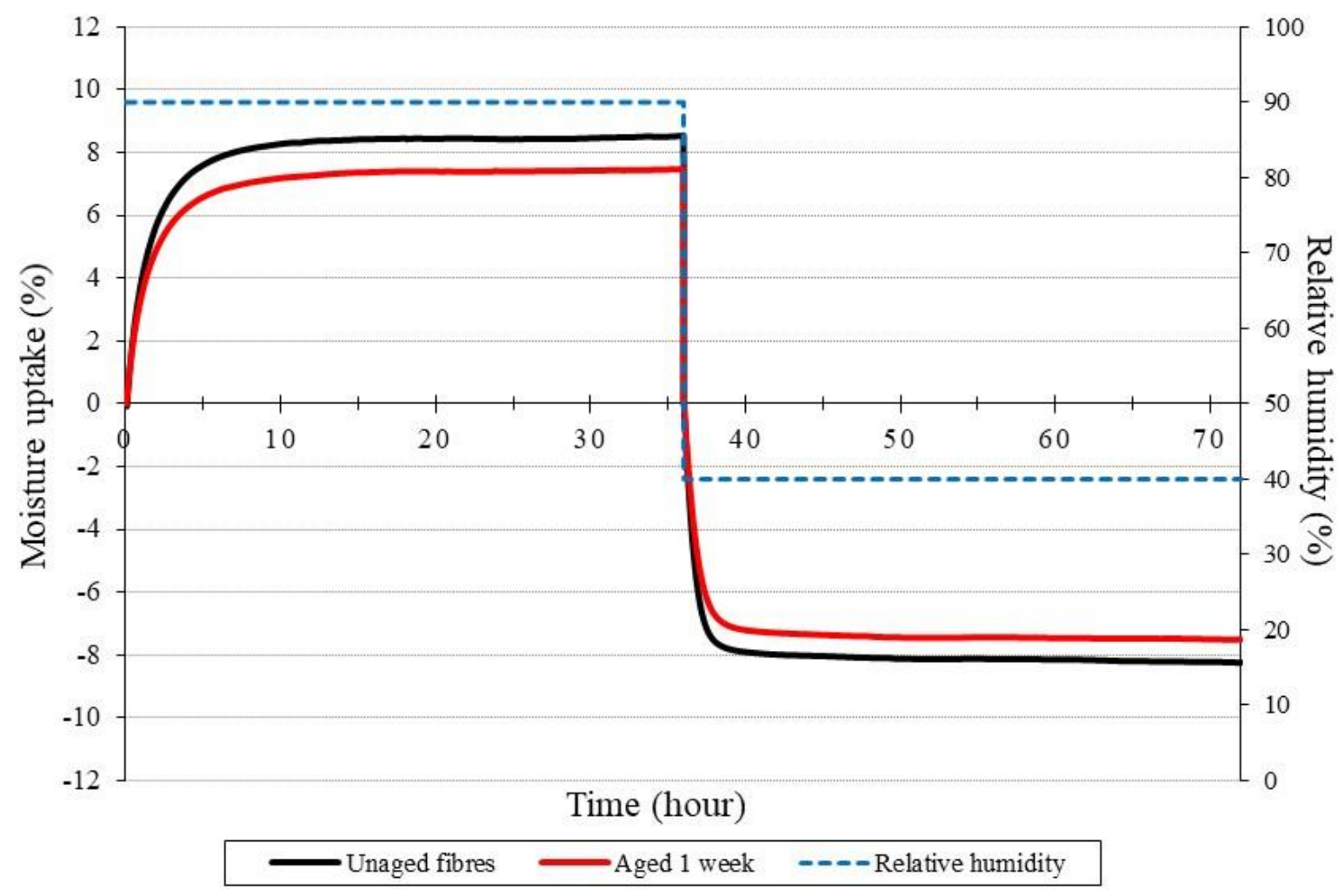

Fig. 7 Thermogravimetric behavior of raw fibers (black line), after 1-week ageing (red line) and Relative Humidity (blue dash line)

It appears that the moisture uptake of raw fibers is slightly higher (15\%) than for 1-week-aged fibers up to $36 \mathrm{~h}$ at $90 \% \mathrm{RH}$. Also, at $40 \% \mathrm{RH}$, the release of water is more important for raw fibers. These results mean that fibers after one week of ageing are less sensitive to humidity than non-aged fibers. This difference could be associated to an extraction of hydrophilic components present in the fibers, such as pectin, hemicellulose and cellulose. Concerning lignin, which is a hydrophobic component, Hill et al. [35] showed by dynamic vapor sorption that moisture nevertheless increases with the lignin fraction. They explain that it is due to the ability of the lignin network to deform and accommodate water within the cell walls.

In order to assess if the decrease of hydrophilic behavior could be related to the fiber surface evolution, Scanning Electron Microscopy (SEM) observations were performed before and after hydrothermal ageing. At the technical fiber scale, fiber surfaces appear cleaner after one week of ageing in water at $80^{\circ} \mathrm{C}$ (Fig. 8). So, components present on the surface of the fibers have been extracted during ageing. However, it seems that elementary fibers are still held together, probably by a part of the middle lamella [8]. Hydrothermal ageing would therefore lead to the extraction of hydrophilic compounds present especially at the surface of the fibers. 


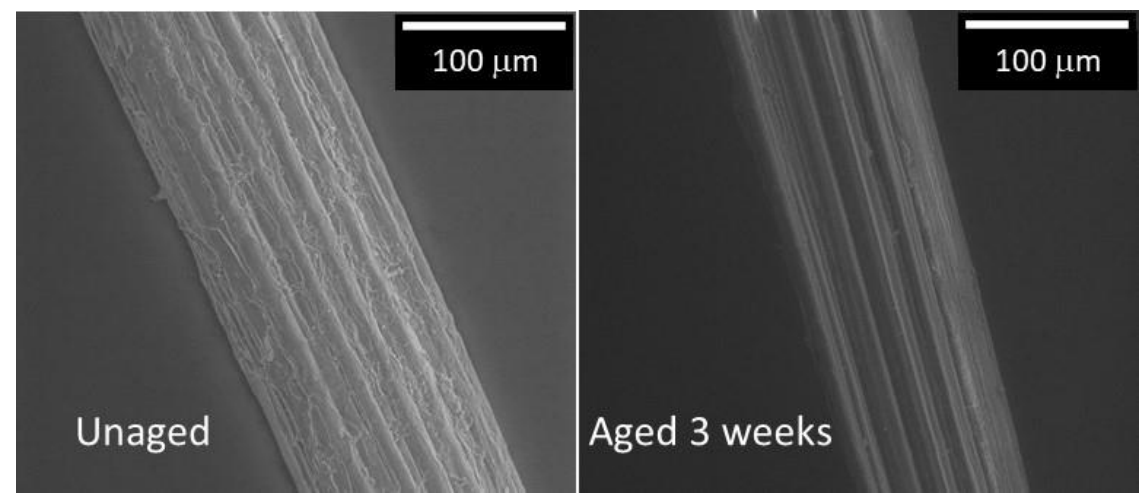

Fig. 8 SEM Scan of technical fiber surfaces before and after 3 weeks of ageing in water at $80^{\circ} \mathrm{C}$

In order to characterize the microstructure of extracted components on the fibers by hot water, X-ray diffraction (XRD) analyses have been carried out.

Fig. 9 shows the evolution of the crystallinity of the fiber as a function of the ageing time.

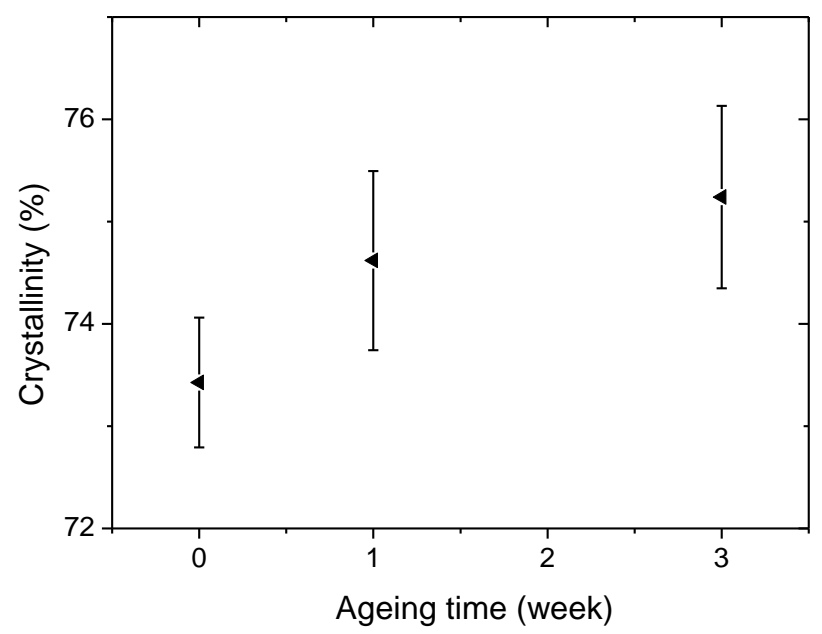

Fig. 9 Crystallinity ratio of the fibers at each ageing time obtained from XRD

The crystallinity ratio slightly increases with ageing time (cf. Fig. 9). This slight increase of crystallinity could be attributed to a part of the amorphous phase which would have been crystallized or have been extracted. With regards to the morphological analysis, extraction by water seems to be favored. Thus, the amorphous phase decreases from 27 to $24 \%$, extraction represents around $10 \%$ of the amorphous phase.

To confirm this interpretation, chemical analysis of fiber was performed. Fig. 10 shows IRTF spectra of fibers before and after water ageing. Spectra were baseline-corrected and normalized at $1160 \mathrm{~cm}^{-1}$ This peak is attributed to the C-O-C stretching asymmetric bridge of the cellulose and does not evolve during ageing $[11,29,30]$. 


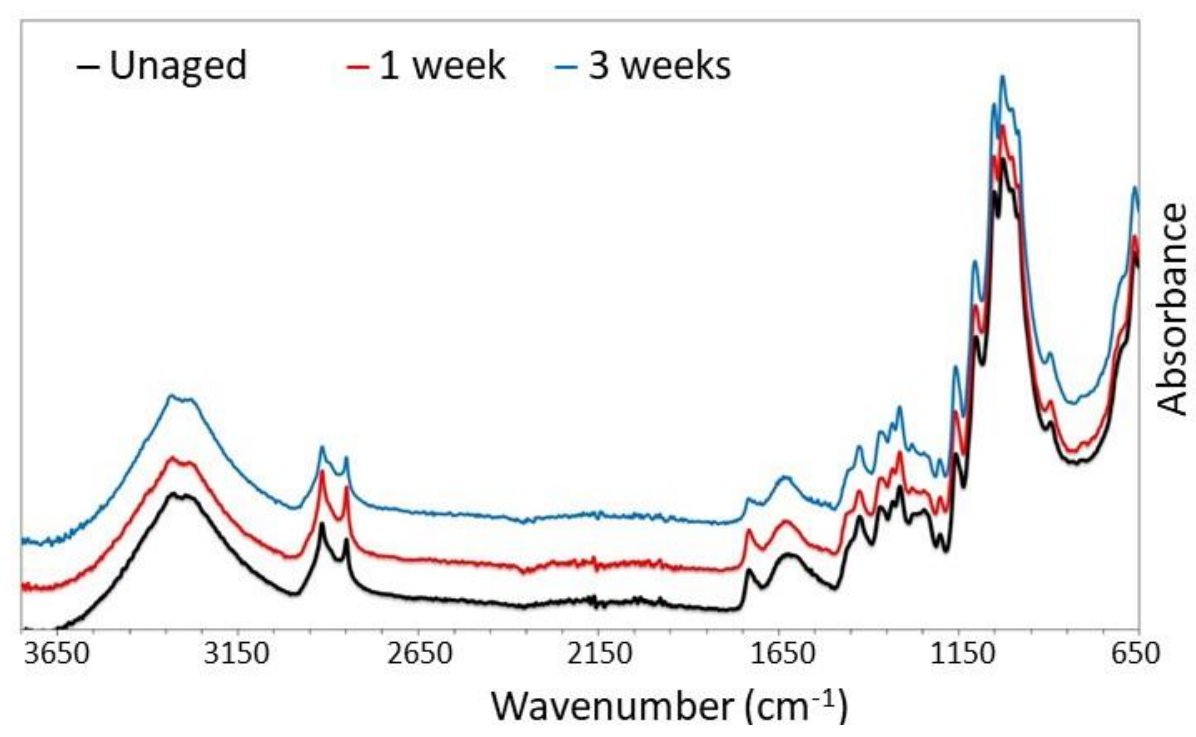

(a)

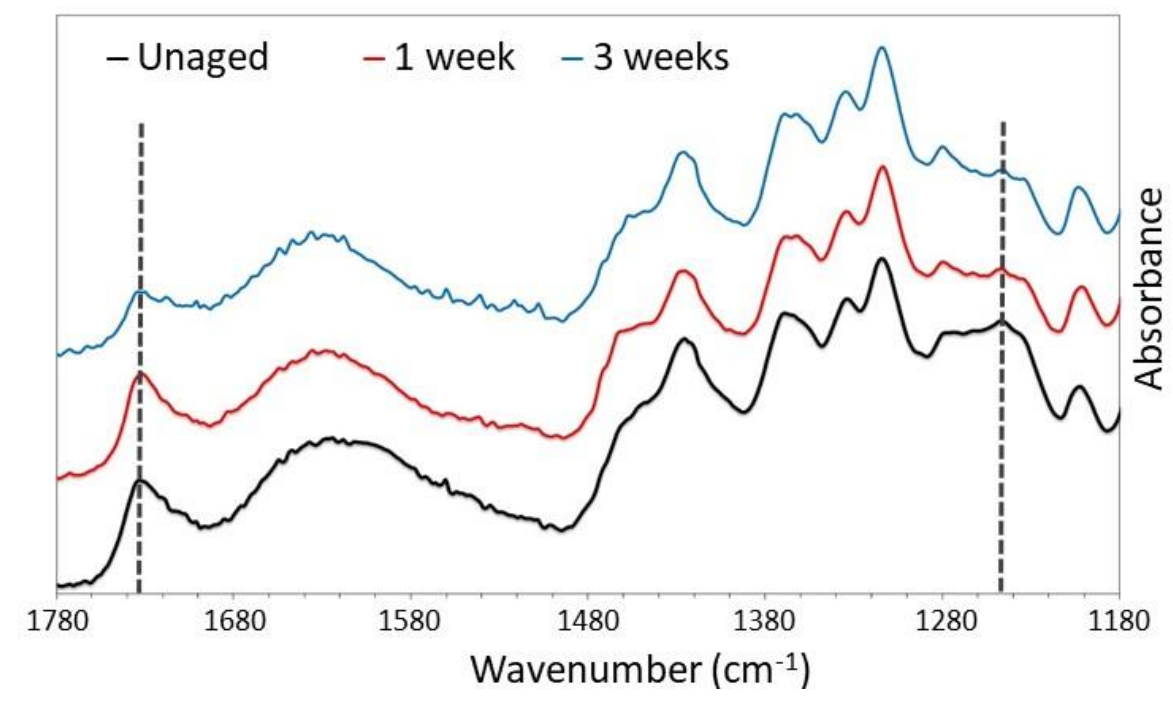

(b)

Fig. 10 Infrared spectra of unaged fibers (black), 1 week-aged (red) and 3 week-aged (blue) (a). Focus on wavenumber between 1780 and $1180 \mathrm{~cm}^{-1}(\mathrm{~b})$

As shown in Fig. 10, water seems to affect bands located at $1247 \mathrm{~cm}^{-1}$ and $1726 \mathrm{~cm}^{-1}$. After one week of ageing in water and even more after three weeks, a decrease of these peaks amplitude has been observed. Peaks at $1726 \mathrm{~cm}^{-1}$ are attributed to $\mathrm{C}=\mathrm{O}$ stretching vibration of hemicellulose ester groups and carboxylic acid groups of pectins [29,30]. The $1247 \mathrm{~cm}^{-1}$ peak corresponds to C-O functions of these groups.

At the end of each ageing time, the liquid of the bath was dried using a rotary evaporator at $70^{\circ} \mathrm{C}$ and a constant pressure of 90 mbar. The dry extract was retrieved, then analyzed. Fig. 11 shows the infrared spectra of dry extracts after 1 week and 3 weeks of immersion in distilled water at $80^{\circ} \mathrm{C}$. Several welldefined peaks and shoulders can be noticed. The assignment of bands and shoulders are shown in Table 3. 


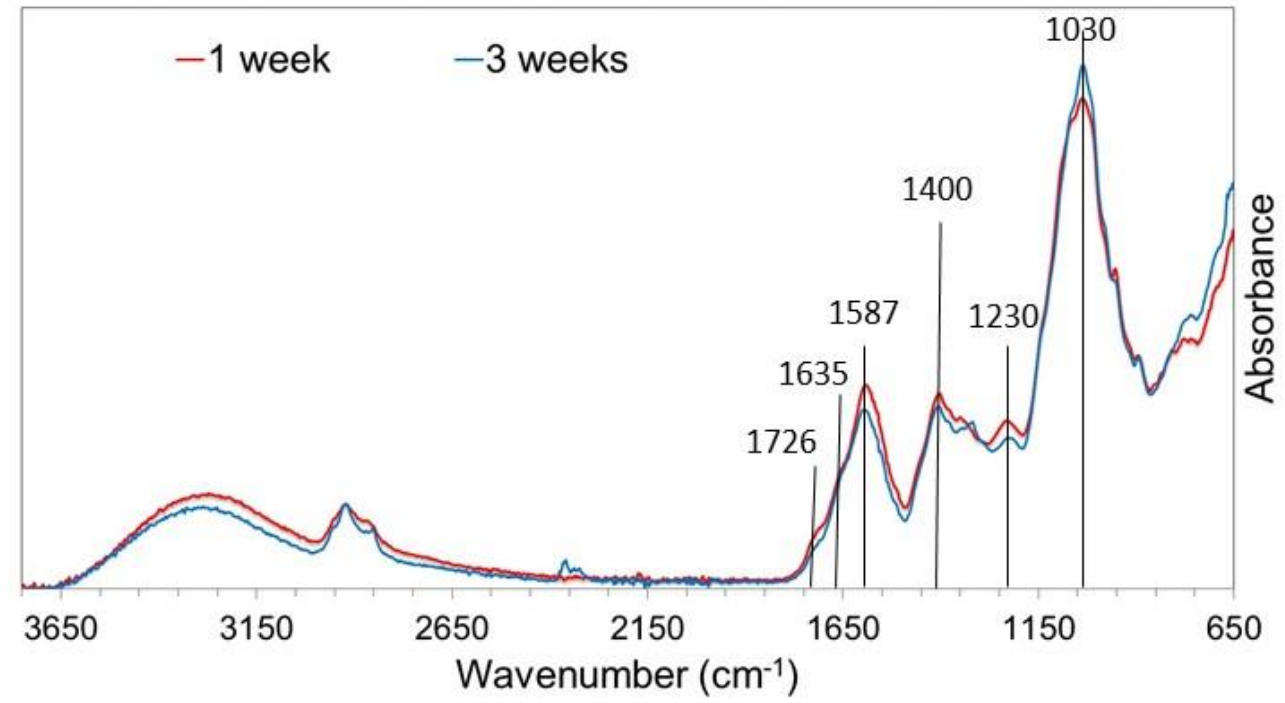

Fig. 11 Infrared spectra of dry extracts after 1 week (red) and 3 weeks (blue) of immersion

\begin{tabular}{|c|c|c|}
\hline Wavenumber $\left(\mathrm{cm}^{-1}\right)$ & Vibration type & Assignment \\
\hline 3300 & $v(\mathrm{O}-\mathrm{H})$ & $\begin{array}{c}\text { Polysaccharides, pectin, hemicellulose, } \\
\text { lignin }\end{array}$ \\
\hline 1726 & $v(\mathrm{C}=\mathrm{O})$ & $\begin{array}{c}\text { Ester and carboxylic acid of pectin and } \\
\text { hemicellulose }\end{array}$ \\
\hline 1635 & $v(\mathrm{C}=\mathrm{O})$ & Acid salt of pectin and/or hemicellulose \\
\hline 1587 & $v(\mathrm{C}=\mathrm{C})$ aromatic & Lignin \\
\hline 1400 & $v\left(\mathrm{COO}^{-}\right)$ & Acid salt of pectin \\
\hline 1230 & $v(\mathrm{C}-\mathrm{O})$ & $\begin{array}{c}\text { Ester and carboxylic acid of pectin and } \\
\text { hemicellulose }\end{array}$ \\
\hline 1030 & $v(\mathrm{C}-\mathrm{O}-\mathrm{C})$ & $\begin{array}{l}\text { Hemicellulose and pectin } \\
\text { and polysaccharides }\end{array}$ \\
\hline
\end{tabular}

Table 3: Absorption bands characteristic of the dry extracts $([30,36,37])$

Firstly, the peak at $1587 \mathrm{~cm}^{-1}$ reveals the presence of aromatic rings found in lignins. Secondly, peaks at $1030 \mathrm{~cm}^{-1}, 1230 \mathrm{~cm}^{-1}, 1400 \mathrm{~cm}^{-1}$, and shoulders at $1635 \mathrm{~cm}^{-1}$ and $1726 \mathrm{~cm}^{-1}$ confirm the extraction of hemicellulose and pectin during the immersion of flax fibers in water at $80^{\circ} \mathrm{C}$.

So, this hydrothermal ageing at $80^{\circ} \mathrm{C}$ until 3 weeks leads to a decrease of tows mechanical properties. The physicochemical analyses have highlighted that this ageing leads to extraction of hydrophilic amorphous components, especially present on the surface of the fibers. The FTIR analyses revealed ester acid and ether functions present in the pectins and hemicellulose. But, as some fiber compounds have similar chemical functions, it was not possible to discriminate the component or components extracted by ageing. This study also reveals the extraction of lignins, consequently, the decrease of tows mechanical properties induced by ageing results from the extraction of amorphous surface compounds such as pectins, hemicelluloses and lignins. 
In this section, we observed the evolution of flax fibers submitted to ageing in hot water. At macroscopic scale, flax fibers become softer and their strength decreases. We also investigated their hydric response and evolution of chemical composition. In the next section, the relationship between the microscale evolution and the macroscale behavior will be discussed.

\section{Discussion}

Based on the mechanical, physical and chemical properties measured while ageing, we performed a multi-scale analysis to identify the degraded components and their effects at macroscopic scale.

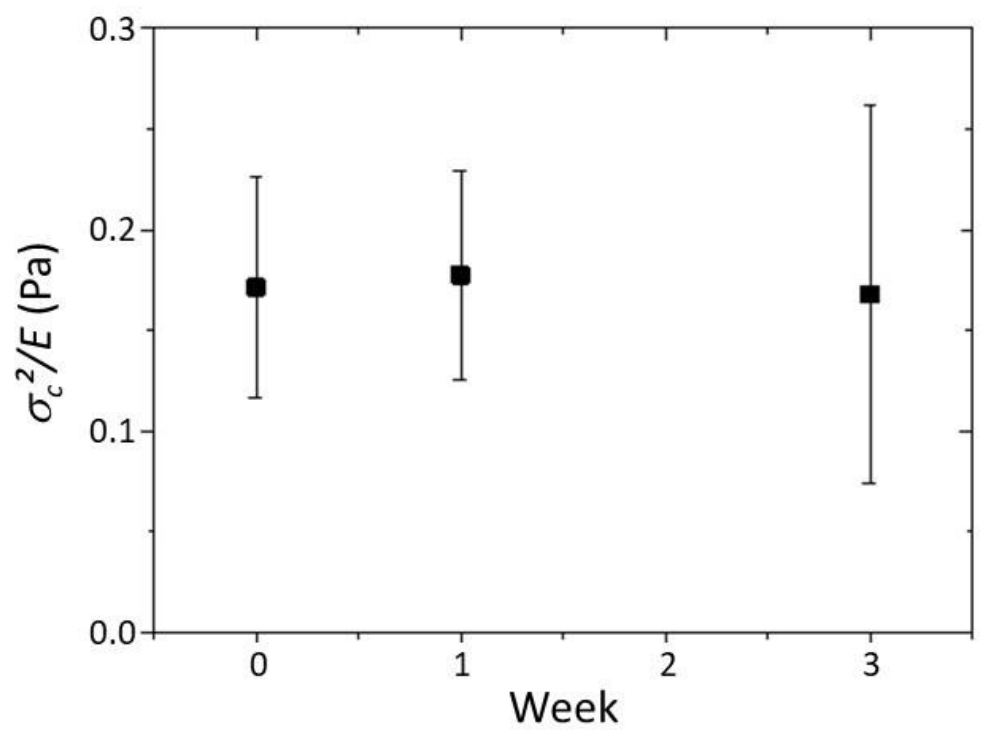

Fig. 12 Evolution of the volumic stored elastic energy $\sigma^{2} / E$ as a function of the number of weeks

At the macroscopic scale, the flax tows show a clear weakening after ageing. The failure of the structure occurs at lower stress. Moreover, the decrease of the elastic modulus and the increase of the critical strain shows that the material is softer than before ageing (see Fig. 6).

Griffith's model is a classic theory to study the mechanical failure, [20, 21, 25, 26, 38]. This theory compares the energy elastically stored to the one needed to propagate a crack from a preexisting microcrack (length $a$ ). It links the strength $\left(\sigma_{c}\right)$ to the elastic modulus $(\mathrm{E})$ as following:

$$
\sigma_{c}=\sqrt{\frac{W \cdot E}{a}}
$$

where $\mathrm{W}$ is the crack surface energy. Thus, $\sigma_{c}^{2} / E$, representing the elastic stored energy as the failure starts, depends mostly on the microcrack length.

Here, the maximal strength and the modulus (cf. Fig. 6) decrease with hydrothermal ageing but the elastic stored energy $\sigma_{c}^{2} / E$ is constant (cf. Fig. 12). Thus, based on equation 1, the characteristic size of microcracks leading to failure is unchanged during ageing. Flaws at the origin of failure are not modified. It suggests that the failure process remains the same. It appears from this analysis that the 
organization of the fibers e.g. the stress localization and the microcracks are not modified by the ageing conditions.

Although the microcracks did not evolved, the macroscopic behavior is strongly affected by ageing. Indeed, the elastic modulus halves during the hydrothermal ageing, thus the material should be affected and becomes homogenously softer. Some authors $[7,8]$ explain these drops in elastic modulus by an increase in diameter due to the cell-wall relaxation. In the case of our study, no increase in diameter was observed

However, based on XRD results (cf. Fig. 9), the extracted components represent less than $10 \%$ of the amorphous phases (25\% of the total mass). Thus, crystalline stiff phase increases its relative fraction during ageing, the general softening of the material is not straightforward. Based on FTIR, we observed an extraction of different amorphous compounds i.e. pectins, hemicelluloses and lignins (see Fig. 10). Amorphous compounds extraction appears to be at the origin of the general softening of the material, suggesting that this phase, in particular pectin which is the natural binder that ensures cohesion between fibers $[15,17]$, plays a major role in the stiffness of the fibers tows but does not modify the flaws at the origin of failure.

\section{Conclusion}

The paper studied the effect of hydrothermal ageing on mechanical properties and embrittlement at the scale of the flax tows. Fibers were immersed in distilled water at a temperature of $80^{\circ} \mathrm{C}$ for different durations. Mechanical properties of tows were studied after weeks of immersion. Tensile tests showed that the maximal force and the stiffness decreased by $31 \%$ and $49 \%$ respectively up to one week and stabilized after three weeks. The failure strain increased by $47 \%$ in the same period, and also stabilized after three weeks. SEM micrographs showed that fibers surfaces appeared cleaner after the ageing. In order to explain these tensile evolutions, chemical and microstructural analyses were performed. Thus, X-ray diffraction and IRTF analysis showed that the crystallinity of fibers increased during the hydrothermal ageing, due to the extraction of amorphous components. By compilation of macroscopic behavior and physicochemical evolutions, it appears that the fiber structure is not modified and extraction of the amorphous components, including pectin, is responsible for the softening of the material.

\section{Acknowledgments}

The authors declare that there is no conflict of interest.

\section{References}

1. Baley C, Goudenhooft C, Gibaud M, Bourmaud A (2018) Flax stems: from a specific architecture to an instructive model for bioinspired composite structures. Bioinspir Biomim 13:026007. 
https://doi.org/10.1088/1748-3190/aaa6b7

2. Baley C, Gomina M, Breard J, et al (2019) Specific features of flax fibres used to manufacture composite materials. Int J Mater Form 12:1023-1052. https://doi.org/10.1007/s12289-018-1455y

3. Baley C, Gomina M, Breard J, et al (2020) Variability of mechanical properties of flax fibres for composite reinforcement. A review. Ind Crops Prod 145:111984. https://doi.org/https://doi.org/10.1016/j.indcrop.2019.111984

4. Baley C, Le Duigou A, Morvan C, Bourmaud A (2018) 8 - Tensile properties of flax fibers. In: Bunsell AR (ed) Handbook of Properties of Textile and Technical Fibres (Second Edition), Second Edi. Woodhead Publishing, pp 275-300

5. Dittenber DB, GangaRao HVS (2012) Critical review of recent publications on use of natural composites in infrastructure. Compos Part A Appl Sci Manuf 43:1419-1429. https://doi.org/https://doi.org/10.1016/j.compositesa.2011.11.019

6. Cicala G, Cristaldi G, Recca G, Latteri A (2010) Composites Based on Natural Fibre Fabrics. In: Woven Fabric Engineering. Sciyo

7. Baley C (2002) Analysis of the flax fibres tensile behaviour and analysis of the tensile stiffness increase. Compos Part A Appl Sci Manuf 33:939-948. https://doi.org/https://doi.org/10.1016/S1359-835X(02)00040-4

8. Lefeuvre A, Duigou A Le, Bourmaud A, et al (2015) Analysis of the role of the main constitutive polysaccharides in the flax fibre mechanical behaviour. Ind Crops Prod 76:1039-1048. https://doi.org/https://doi.org/10.1016/j.indcrop.2015.07.062

9. Gorshkova T, Brutch N, Chabbert B, et al (2012) Plant Fiber Formation: State of the Art, Recent and Expected Progress, and Open Questions. CRC Crit Rev Plant Sci 31:201-228. https://doi.org/10.1080/07352689.2011.616096

10. Lefeuvre A, Bourmaud A, Morvan C, Baley C (2014) Elementary flax fibre tensile properties: Correlation between stress-strain behaviour and fibre composition. Ind Crops Prod 52:762-769. https://doi.org/https://doi.org/10.1016/j.indcrop.2013.11.043

11. Alix S, Colasse L, Morvan C, et al (2014) Pressure impact of autoclave treatment on water sorption and pectin composition of flax cellulosic-fibres. Carbohydr Polym 102:21-29. https://doi.org/https://doi.org/10.1016/j.carbpol.2013.10.092

12. Lamon J, R'Mili M, Reveron $\mathrm{H}$ (2016) Investigation of statistical distributions of fracture strengths for flax fibre using the tow-based approach. J Mater Sci 51:8687-8698. https://doi.org/10.1007/s10853-016-0128-9

13. Baley C, Bourmaud A (2014) Average tensile properties of French elementary flax fibers. Mater Lett 122:159-161. https://doi.org/10.1016/j.matlet.2014.02.030

14. Stamboulis A, Baillie CA, Peijs T (2001) Effects of environmental conditions on mechanical and physical properties of flax fibers. Compos Part A Appl Sci Manuf 32:1105-1115. https://doi.org/https://doi.org/10.1016/S1359-835X(01)00032-X

15. Moothoo J, Allaoui S, Ouagne P, Soulat D (2014) A study of the tensile behaviour of flax tows and their potential for composite processing. Mater Des 55:764-772. https://doi.org/https://doi.org/10.1016/j.matdes.2013.10.048

16. Bos HL (2004) The potential of flax fibres as reinforcement for composite materials, Eindhoven

17. Beakou A, Charlet K (2013) Mechanical properties of interfaces within a flax bundle-Part II: Numerical analysis. Int $J$ Adhes Adhes 43:54-59. https://doi.org/https://doi.org/10.1016/j.ijadhadh.2013.01.013

18. Charlet K, Béakou A (2011) Mechanical properties of interfaces within a flax bundle - Part I: Experimental analysis. Int $J$ Adhes Adhes 31:875-881. https://doi.org/https://doi.org/10.1016/j.ijadhadh.2011.08.008

19. Romhány G, Karger-Kocsis J, Czigány T (2003) Tensile fracture and failure behavior of technical flax fibers. J Appl Polym Sci 90:3638-3645. https://doi.org/10.1002/app.13110

20. Griffith AA, Taylor GI (1921) VI. The phenomena of rupture and flow in solids. Philos Trans R Soc London Ser A, Contain Pap a Math or Phys Character 221:163-198. https://doi.org/10.1098/rsta.1921.0006 
21. Griffith AA. (1924) The theory of rupture. In: Proc. Int. Congr. Appl. Mech. pp 56-63

22. Shah, SP; McGarry F (1971) Griffith fracture criterion and concrete. ASCE J Eng Mech Div 97:1663-1676

23. Xiao ZM, Chen BJ (2001) Stress analysis for a Zener-Stroh crack interacting with a coated inclusion. Int J Solids Struct 38:5007-5018. https://doi.org/https://doi.org/10.1016/S00207683(00)00335-8

24. Lazarus $V(2017)$ Fracture spacing in tensile brittle layers adhering to a rigid substrate. EPL (Europhysics Lett 117:24002. https://doi.org/10.1209/0295-5075/117/24002

25. Rice JR (1968) A Path Independent Integral and the Approximate Analysis of Strain Concentration by Notches and Cracks. J Appl Mech 35:379-386. https://doi.org/10.1115/1.3601206

26. Rice JD. (1968) Mathematical analysis in the mechanics of fracture. MAth Fundam 2:191-311

27. Dubois F, Chazal C, Petit C (2002) Viscoelastic crack growth process in wood timbers: An approach by the finite element method for mode I fracture. Int J Fract 113:367-388. https://doi.org/10.1023/A:1014203405764

28. Mokhothu TH, John MJ (2015) Review on hygroscopic aging of cellulose fibres and their biocomposites. Carbohydr Polym 131:337-354. https://doi.org/https://doi.org/10.1016/j.carbpol.2015.06.027

29. Célino A, Fréour S, Jacquemin F, Casari P (2014) The hygroscopic behavior of plant fibers: a review. Front Chem 1:43. https://doi.org/10.3389/fchem.2013.00043

30. Célino A, Gonçalves O, Jacquemin F, Fréour S (2014) Qualitative and quantitative assessment of water sorption in natural fibres using ATR-FTIR spectroscopy. Carbohydr Polym 101:163170. https://doi.org/https://doi.org/10.1016/j.carbpol.2013.09.023

31. Thuault A, Eve S, Blond D, et al (2014) Effects of the hygrothermal environment on the mechanical properties of flax fibres. J Compos Mater 48:1699-1707. https://doi.org/10.1177/0021998313490217

32. Le Duigou A, Bourmaud A, Davies P (2011) Etude des mécanismes d'adhérence entre une fibre de lin et le PLLA- Influence d'un traitement faiblement impactant à l'eau Study of adherence mechanism between flax fibre and PLLA matrix- Influence of low environmental impact water treatment. Science (80- ) 1-9

33. Bourmaud A, Morvan C, Baley C (2010) Importance of fiber preparation to optimize the surface and mechanical properties of unitary flax fiber. Ind Crops Prod 32:662-667. https://doi.org/https://doi.org/10.1016/j.indcrop.2010.08.002

34. Tserki V, Zafeiropoulos NE, Simon F, Panayiotou C (2005) A study of the effect of acetylation and propionylation surface treatments on natural fibres. Compos Part A Appl Sci Manuf 36:11101118. https://doi.org/https://doi.org/10.1016/j.compositesa.2005.01.004

35. Hill CAS, Norton A, Newman G (2009) The water vapor sorption behavior of natural fibers. J Appl Polym Sci 112:1524-1537. https://doi.org/10.1002/app.29725

36. Moine C (2005) Extraction, caractérisation structurale et valorisation d'une famille d'hémicelluloses du bois: Obtention de matériaux plastiques par modification des xylanes. Université de Limoges

37. Lu Y, Miller JD (2002) Carboxyl Stretching Vibrations of Spontaneously Adsorbed and LBTransferred Calcium Carboxylates as Determined by FTIR Internal Reflection Spectroscopy. J Colloid Interface Sci 256:41-52. https://doi.org/https://doi.org/10.1006/jcis.2001.8112

38. Irwin GR. (1957) Analysis of stresses and strains near the end of a crack transversing a plate. Trans ASME, Ser E, J Appl Mech 24:361-364

\section{Appendix}

The flax fibers used in these studies had the following composition 
Cellulose wt $\% \quad$ Hemicellulose wt\% $\quad$ Pectin wt $\% \quad$ Lignin wt $\%$ Waxes wt $\%$ Water wt $\%$ 83,8 2,5 4,2 2,3 4,8 7 